\title{
Skeleton Writing in Chinese Universities: Truly Effective?
}

\author{
Qingbo Yang \\ Ludong University, Yantai, China \\ Email: Talkshow2000@eyou.com
}

\begin{abstract}
English Writing Test is considered to be one of the most effective measures in SLL and SLT. In China, in order to improve the students writing performance in tests, skeleton writing is widely employed in college English teaching. As a result, it is not surprising to see skeleton writing being desperately used in all sorts of writing tests, ranging from College English Test Band 4 and College English Test Band 6 (known as CET4 and CET6) to postgraduate entrance examination. However, some people have doubted about the effectiveness of skeleton writing. In order to explore the effectiveness of skeleton writing, a survey was conducted in the Chinese academic year of 2008 and 2009 in eastern China. Results of this survey suggest that although most training staffs attached great importance to skeleton writing, students, especially those with relative low English level, can hardly benefit from it. This essay aims to offer the conclusion that skeleton writing is really of some help for few, but not for so many as has been expected.
\end{abstract}

Index Terms—skeleton writing, college English test, China, effectiveness

\section{BACKGROUND}

Skeleton writing, (someone named it as model writing (Connors,1981), an equivalent to its Chinese version 模板作 文) a term maybe not new to western academic circle (the English version maybe new to Chinese), has been a hot topic in China. What is skeleton writing? Generally speaking, it means that, before you write, something has already been written for you and this is called the skeleton and what you need to do is to stuff the skeleton with flesh and blood (Appendix A). It is expected that with the help of skeleton, writers could write well and better in practice. Some native speakers of English employ skeleton writing as a technique in their writing instructions. "I can create an outline - a sentence outline - for a five paragraph essay on an assigned topic in two shakes of a lamb's tail. So can your

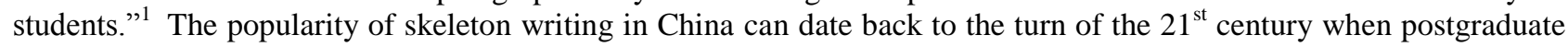
examination was drawing more and more people's attention. At that time, some English training staffs first brought up the concept of "skeleton writing" with an attempt to help the students get a good score in English writing tests. From then on, the term "skeleton writing" became popular with both teachers and students and it has been widely used in all sorts of English examinations, for example, CET4\&6, postgraduate entrance examinations, even college entrance examinations.

There is some debate, however, about the effectiveness of skeleton writing in English writing tests. Students, especially those with relatively low English level, applaud for skeleton writing. In their opinion, the use of skeleton writing is a guarantee for a high score, or at least, an eraser for the distinction of being poor or good at English writing. Also, some teachers, even scholars think high of skeleton writing. They believe that skeleton writing, if used properly, could improve the students' writing performance; thus they spare no efforts to introduce skeleton writing to students.

Taking a contrary view to this position, some people argue against such attitudes, worrying that their use of skeleton writing is based on a thorough misunderstanding of English writing and its side-effect may be far-reaching. As a matter of fact, skeletons, or models in writing instruction have survived for centuries (Corbett, 1965 and Covino, 1988) and criticism of them has arisen for nearly as long. The most common complaint about skeleton writing or model writing in English - the five-paragraph essay - is that it induces formulaic, empty writing. To them, skeleton writing, on the one hand, has cornered the students' imagination, inhibited students' identities as writers, and on the other hand, distorted or misrepresented the processes of English writing, which might result in exam-oriented education to a large extent. (Connors, 1981; Elbow, 1973; Johns, 1995; Leki, 1995; Murray, 1985; Shih, 1986; Silva, 1999; Spack, 1988).

If the Chinese university at which I am teaching is of any indication, there is certainly enough Evidence to suggest that skeleton writing occurs on a large and regular basis in Chinese higher education. College English teachers are continuously discovering that writings submitted to them by their students have had skeleton writing traces. What's more, it is not unusual to see in many English tests students have employed skeleton writing. For example, CET4\&6. Is skeleton writing really academically acceptable in Chinese universities? Is it really effective in improving students' writing performance? Or, is it really of any help in improving students' English writing? The purpose of the present study is to explore the effectiveness of skeleton writing among Chinese students as well as English teachers. To do so, I

\footnotetext{
${ }^{1}$ www.you-can-teach-writing.com/create -outline.html
} 
make an attempt to see both the teachers' and students' reactions to skeleton writing.

\section{SURVEY METHODOLOGY}

At the end of the second semester, all the freshmen of 2008 in Ludong University participated in their English final examination (which is usually called College English Test Band 1). Table 1 shows the results of the six departments and Table 2 shows overall totals of the freshmen. There were no apparent differences in their measures. And also, these scores were similar to the overall total mean.

TABLE 1

CET BAND 2 RESULTS FOR STUDENTS FROM 6 DEPARTMENTS.

\begin{tabular}{|c|c|c|c|c|c|}
\hline Department & $\mathrm{N}$ & Minimum score & Maximum score & $\mathrm{x}$ & SD \\
\hline Chinese & 478 & 58 & 86 & 76.51 & 8.24 \\
\hline History & 287 & 56 & 87 & 77.03 & 8.68 \\
\hline Economics & 254 & 48 & 84 & 75.96 & 9.13 \\
\hline Physics & 463 & 44 & 86 & 75.87 & 8.76 \\
\hline Computer & 356 & 28 & 84 & 73.45 & 9.25 \\
\hline Civil Engineering & 347 & 33 & 88 & 73.46 & 8.76 \\
\hline
\end{tabular}

TABLE 2

CET BAND 2 RESULTS FOR ALL FRESHMEN OF 2008 EXCEPT THOSE OF P.E. DEPARTMENT

\begin{tabular}{|c|c|c|c|c|c|}
\hline & $\mathrm{N}$ & Minimum score & Maximum score & $\mathrm{x}$ & $\mathrm{SD}$ \\
\hline total & 3466 & 18 & 91 & 74.37 & 20.45 \\
\hline
\end{tabular}

( $\mathrm{N}=$ number, $\mathrm{x}=$ mean, $\mathrm{SD}=$ standard deviation)

Two classes, Class A and Class B, with 63 students respectively, participated in the study, which was conducted in the $3^{\text {rd }}$ semester. Class A is composed of students from 2 departments, Chinese Department (31) and Civil Engineering Department (32) while Class B is made up of 63 among which 32 are from History Department and 31 from Computer Department.

In this study, Class A was exposed to the normal writing techniques and writing procedures (for example, the brainstorming, outline, proofreading, to name just a few) while Class B was equipped with skeletons only. A writing test followed immediately after the writing instruction of the two classes. In the test, the students were asked to write an article based on the outline given in 30 minutes in no less than 120 words (Appendix B).

To minimize the potential drawbacks caused by skeleton writing and to minimize the potential weakness of conventional writing teaching, in the forth semester, skeleton writing and conventional writing are both conveyed to Class A and Class B respectively.

A brief survey followed the writing test immediately for Class B. During the survey, the students of Class B were asked to answer some questions concerning their writing classes and writing test. The question-based survey was in both Chinese and English and the students could choose either Chinese or English when answering questions.

Next, a case study was conducted. The title of the CET 6 of 2009 English writing is "Should Parents Send Their Kids to Arts Classes?" Out of so many skeleton writings, the present writer picked up one and invited 67 college English teachers to score it independently. Then the article was taken to Jinan, the capital city of Shandong Province, which is one of the six scoring centers of China. There, the writing was scored again by another 67 teachers, who have undertaken the CET writing scoring for more than once and have accumulated some knowledge about skeleton writing.

\section{RESULTS}

\section{A. Writing Test}

Table 3 and Table 4 indicates the writing scores of Class A and Class B (15 points being the full score)

TABLE 3

\begin{tabular}{|c|c|c|c|c|c|}
\hline Class A & $\mathrm{N}$ & Minimum score & Maximum score & $\mathrm{x}$ & SD \\
\hline Chinese Department & 31 & 7 & 12 & 9.32 & 1.61 \\
\hline Civil Engineering Department & 32 & 6 & 13 & 8.91 & 1.63 \\
\hline
\end{tabular}

TABLE 4

\begin{tabular}{|c|c|c|c|c|c|}
\hline Class B & $\mathrm{N}$ & Minimum score & Maximum score & $\mathrm{x}$ & SD \\
\hline History Department & 32 & 4 & 14 & 9.03 & 2.86 \\
\hline Computer Department & 31 & 3 & 14 & 8.55 & 3.01 \\
\hline
\end{tabular}

From the chart above, we can see that, there is subtle difference between the two classes after one-semester's writing 
training. The mean score of the two classes is almost the same. However, there are 9 students from class B who scored more than 11 points while there are only 6 from class A. However, there are 21 who scored below 8 in Class B while in Class A the number is 12 .

\section{B. Question-based Survey}

In the survey followed the writing test, students from Class B were generally positive in their response to skeleton writing, satisfied that it served as a wonder drug to their headache of English writing. "It is a wonder for me. I really wonder why my high school teacher didn't teach us that kind of skeleton writing," commented one. Another noted, "My English is poor, but I am sure I do well this time. I even admire my writing. It saved me lots of time."

But, still, a few held opposite ideas. "I could write nothing else down except the skeleton, and I don't know how to fill in and what to fill in the skeleton." Another wrote, "It looks like eight-part essays. ${ }^{2}$ Is it the genuine English writing?"

\section{Case Study}

Table 5 shows the scores of one of the CET 6 writings " Should Parents Send Their Kids to Art Classes" (Appendix D), scored by 67 English teachers of Ludong University.

\begin{tabular}{|c|c|c|c|c|c|}
\hline & $\mathrm{N}$ & Minimum score & Maximum score & $\mathrm{x}$ & $\mathrm{SD}$ \\
\hline English teachers & 67 & 2 & 12 & 7.25 & 2.31 \\
\hline
\end{tabular}

Table 6 indicates the scores of the same writing "Should Parents Send their kids to Art Classes?", scored by another 67 English Teachers who are familiar with skeleton writing.

\begin{tabular}{|l|c|c|c|c|c|}
\hline \multicolumn{1}{|c|}{ TABLE 6 } \\
\hline & $\mathrm{N}$ & Minimum score & Maximum score & $\mathrm{x}$ & SD \\
\hline Scoring teachers & 67 & 2 & 10 & 4.66 & 1.37 \\
\hline
\end{tabular}

In the two scorings, the highest score was12, and the mean of Table 6 was much lower than that of Table 5 .

Responses from the two groups of teachers were different too. The following is a sampling of the comments from some teachers, with their scores in parentheses.

Teachers scoring for Table 5

- I am surprised at his writing. Quite good at structuring and writing. (11)

- He could write good English. (11)

- Excellent at English writing. (12)

- He writes well in some parts but fails in other parts. (10)

- He is imitating to some extent, and it works. (9)

- He is coping some sentences and we can hardly see his own writing. (2)

Teachers scoring for Table 6

- Absolutely coping! (2)

- No flesh, no blood, except the skeleton! (2)

- He steals the structure. ( 3 )

- What he lacks is his own writing. (4)

- Excellent at some parts ( obviously coping) and rather poor at his own writing. (3)

- It is surprising that he has a very good memory at memorizing the structure but could not improve his English writing. (3)

Many other comments reflect similar sentiments to the above.

Overall, the 67 teachers from the scoring center thought that the writing was nothing but a failure.

\section{DISCUSSION: IS SKELETON WRITING REALLY EFFECTIVE?}

The scores and accompanying comments by the 67 teachers from the scoring center seemingly contradict Class B's generally positive idea that skeleton writing is a wonder drug to cure their headache of writing. We can also see contradicting ideas among English teachers (67 of my colleagues, for example). Even in Class B alone, there are different opinions about the effectiveness of skeleton writing.

Is skeleton writing effective? It seems, at least to some extent, to be. In the study of Class A and Class B, nine

\footnotetext{
${ }^{2}$ It is a kind of examination-oriented essay which could date back to Ming Dynasty when the participants of imperial competitive examination had to adopt the form of the fixed eight parts in their writing. It was notorious for its bandage of intellectuals' imagination and thought and was abolished in Qing Dynasty.
} 
students from Class B scored more than 11 points and the number in Class A was only 6. Also, the highest score (14) was in Class B.

Is skeleton writing really effective? It seems not. Garfinkel and Sacks (1970) stress that there must be certain shared understandings about the insufficiencies of models (skeletons). Writers must know the limits of the model. He or she must know that the model has intentional insufficiencies. Let's take another look at the study of Class A and Class B. Twenty-one students from Class B scored below 8 points and the number in Class A was only 12. Also, in the question-based survey, more than few students held negative, or at least, suspected ideas about skeleton writing, including those who scored more than 8 .

- "I could write down nothing else except the skeleton and I don't know how to fill in and what to fill in the skeleton."(4/15)

• "It looks like eight-part essays. Is it the genuine English writing?" (11/15)

As for the sample writing, "Should Parents Send Their Kids to Art Classes?", the responses from the scoring center are further indications of some teachers' negative attitude, even hate, toward skeleton writing.

Taking all these factors into consideration, skeleton writing is not as effective as that has been expected and publicized. We say that it is effective only in that it can help students grasp the structure of the composition and only those whose English is good enough to manipulate it can develop the skeleton fully, can endow the skeleton with blood and flesh and make it vivid and live. In other words, only those with good English can benefit from skeleton writing and make it to its full potential. Otherwise, it served as nothing but a bondage to students' imagination and improvement, which is obviously against the expected function of skeleton writing.

For ordinary students and the sort below, skeleton writing is rather misleading. Models (skeletons) do not easily transfer to other writing tasks and models represent writing styles too narrowly (Elbow, 1994; Moffett, 1982; Murray, 1985; Swales, 1997). Skeleton writing in question is effective only in some argumentative writings (Should Parents Send their Kids to Art Classes? Say). Once faced up with other forms of writing, for example, expository writing or descriptive writing, Students would be at loss and in this case skeleton shows them no direction at all. If some of them accidentally get a high score with skeleton writing, the scoring teacher must be dozy off while scoring. For those who have been publicizing skeleton writing, generally speaking, there are only two purposes, if not the later one alone: to help students pass writing tests and to make money from various kinds of training programs or test-oriented books. It is not easy to write in either one's native language or second language. There is no shortcut in learning English writing. Only by writing can one learn to write. Only when one has a good command over English can he benefit some, not too much as has been publicized, from skeleton writing. Skeleton is the means, not the ends in writing.

\section{CONCLUSION}

Limitations to this study cannot be neglected. First, there is the matter of how much exposure students from Class A have experienced with the so popular skeleton writing. Though we have tried to keep them from that concept and tried to input conventional writing techniques, they are not living in vacuum thoroughly immune to outside circumstances.

Second, there is another matter of how much knowledge the 67 teachers of my colleagues have got about skeleton writing before they scored the sample writing. As far as I know, some of them are in strong favor of skeleton writing, training their students with great effort.

Despite the above points, the results suggest that we, especially English teachers, should be careful about concluding that skeleton writing is effective and is of great help to improve students' English writing.

Many people, varying from college English teachers to training program teachers, still teach students to write in skeleton forms, assuming that they will get a high score with it. Many students follow the suit, believing blindly that skeleton writing will help them stand out from so many ordinary writings and help them win in the end.

In fact, skeleton writing will not work unless you have an excellent command over English and know very well about conventional English writing (writing procedures, writing techniques, to name just a few). There is a popular proverb going like this: "When you give somebody a fish, he has a meal. But if you teach him to fish, he can make a living himself." thus we should teach them to fish, not teach them just to wait for the smelly fish.

\section{APPENDIX A. A SAMPLE SKELETON}

It is generally believed that ... is a hot topic which is widely talked about both at home and abroad. As for this topic, different people have different ideas.

There are many advantages which are closely related to this situation. In the first place...; In the second place...; What's more...

However, ... has also brought us some disadvantages. On the one hand,... On the other hand, ...for example....

In my opinion, we should make every effort to come out with possible solutions to this problem. As soon as this problem is solved or even partially relieved, we are bound to have a much bright future.

\section{APPENDIX B. DIRECTIONS FOR THE WRITING TEST}

Directions: For this part, you are allowed 30 minutes to write a short essay entitled Keeping Pets .You should write at 
least 120 words following the outline given below.

1. The advantage of keeping pets

2. The disadvantage of keeping pets

2. Your opinion

APPENDIX C.

The following is an article written by a university student in College English Examination Bank 6 in 2009. The directions are as follows:

Directions: For this part, you are allowed 30 minutes to write a short essay entitled Should Parents Send Their Kids to Art Classes? You should write at least 150 words following the outline given below.

现在有不少家长送孩子参加各种艺术班

1、对这种做法有人表示支持

2、有人并不赞成

3、我认为......

Should Parents Send Their Kids to Art Classes?

Whoever in front of this subject will be greatly shocked. What is conspicuously illustrated in this topic about is that parents send their kids to art classes. Odd and funny as it seems to be, such happening are so wide spread that we cannot afford to ignore them.

Obviously we can easily define that the subject intends to reflect to us and the strong and deep message suggested here is that art classes have two sides. It will change some students' life and it also have harm to somebody. It is alarming that similar events are available in nearly all walks of life. If such stories go unchanged, it is hard to imagine that our society will be like years later. Failure to realize the severity of this grim situation will inevitably to decrease of chances of success. As a result, parents send their kids to art classes is harmfully.

Much can be done. What tops the agenda, I deem, is to help people develop a wholesome outlook on life and to cultivate noble and worthy value and qualities among them. Moreover, we should appeal the government to take nation-wide prompt actions. All the society should make sustained and controlled efforts to curb such practices. Only in this way, can we maintain a happy and health society as we as wish.

\section{REFERENCES}

[1] Connors, R. J. (1981). The rise and fall of the modes of discourse. College Composition and Communication 34, pp. 444-455.

[2] Corbett, E. (1965). Classical rhetoric for the modern student. Oxford University Press, New York.

[3] Covino, W. (1988). Defining advanced composition: Contributions from the history of rhetoric. Journal of Advanced Composition 8, pp. 113-122.

[4] Elbow, P. (1973). Writing without teachers. Oxford University Press, New York.

[5] Elbow, P. (1994). What do we mean when we talk about voice in texts?. In: K. Yancey, Editor, Voices on voice: Perspectives, definitions, inquiry, National Council of Teachers of English, Urbana, IL, pp. 1-35.

[6] Garfinkel and Sacks, H. (1970). On formal structure of practical actions. In: J.C. McKinney and E.A. Tiryakian, Editors, Theoretical Sociology, Appleton-Crofts, New York, pp. 337-365.

[7] Johns, A. (1995).Teaching classroom and authentic genres: Initiating students into academic cultures and discourses. In: D. Belcher and A. Hirvela, Editors, Academic writing in a second language: Essays on research and pedagogy, Ablex, Norwood, NJ, pp. 277-291.

[8] Leki, I. (1995).Coping strategies of ESL students in writing tasks across the curriculum. TESOL Quarterly 29, pp. $235-260$.

[9] Moffett, J. (1982). Writing, inner speech and mediation. College English 44, pp. 231-244.

[10] Murray, D. Murray. (1985). A writer teaches writing (2nd Ed.). Houghton Mifflin, Boston.

[11] Shih, M. (1986). Content-based approaches to teaching academic writing. TESOL Quarterly 20, pp. 617-648.

[12] Silva, T. (1999). On the ethical treatment of ESL writers. TESOL Quarterly 33, pp. 359-363.

[13] Spack, R. (1988). Initiating ESL students into the academic discourse community: How far should we go?, TESOL Quarterly 22, pp. 29-51.

[14] Swales, J. (1997). English as tyrannosaurus rex. World Englishes 16, pp. 373-382.

Qingbo Yang was born in Yantai, China in 1971. He received his M.A. degree in linguistics from Shandong University, China in 2002.

He is currently an associate professor in the Department of Foreign Languages Teaching, Ludong University, Yantai, China. His research interests include EFLT and American novels.

Prof. Yang is a member of the Chinese Association of Foreign Language Teachers. 